\title{
WZROST ZNACZENIA UDZIALU MILITARNEGO PAŃSTW BALTYCKICH I POLSKI W RAMACH NATO PO KRYZYSIE UKRAIŃSKIM
}

\begin{abstract}
Aneksja Krymu i zagarnięcie dwóch obwodów Ukrainy przez Rosję lub wspierane przez nią prorosyjskie formacje zbrojne w 2014 r. doprowadziły do wyraźnego wzrostu geopolitycznego znaczenia wschodniej flanki NATO. W szczególności odnosiło się to do czterech państw położonych w centralnej części wschodniej granicy sojuszu: Estonii, Łotwy, Litwy i Polski. Znacznie mniej zauważalny, choć nie mniej istotny, był wzrastający w latach 2014-2018 udział potencjału militarnego tych państw w stosunku do całego potencjału (wszystkich krajów) NATO. Objęcie funkcji prezydenta USA przez Donalda Trumpa w styczniu $2017 \mathrm{r}$. i jego żądania dotyczące zwiększenia wydatków na obronność wśród członków NATO tylko przyśpieszyło zmiany $\mathrm{w}$ tym zakresie $\mathrm{w}$ wielu państwach. Zmiany te dotyczyły zakupu sprzętu wojskowego, tworzenia nowych organizacji wojskowych, jak chociażby Wojsk Obrony Terytorialnej w Polsce czy próby uniezależnienia się od Rosji w kwestiach energetycznych. Przewidywania m.in. Fukuyamy o końcu historii nie sprawdziły się, obecnie tylko posiadanie własnych dość licznych i nowoczesnych sił zbrojnych, przeznaczanie na ten cel odpowiedniej liczby wydatków budżetowych oraz posiadanie sojuszników może jedynie zagwarantować bezpieczeństwo dla państw. W rezultacie dokonanych analiz autorzy stwierdzili, że w największym stopniu udział potencjału militarnego dotyczył m.in. kwestii: zwiększenia stanów osobowych sił zbrojnych (w szczególności sił lądowych) oraz wydatków wojskowych. Choć, największą dynamikę w obu przytoczonych parametrach wykazywała Litwa (co zarazem umiejscawiało ją pod tym względem na pierwszym miejscu w całym Pakcie Północnoatlantyckim), to - tradycyjnie, tak jak przed 2014 rokiem - najwyższe stany osobowe sił zbrojnych nadal utrzymywała Polska, a najwyższy udział wydatków wojskowych w stosunku do PKB - Estonia. Jednak największy wkład do potencjału NATO ze strony analizowanych państw (a konkretnie tylko Polski) dotyczył relatywnie dużej liczby czołgów.
\end{abstract}

Słowa kluczowe: NATO, potencjał, PKB, siły zbrojne.

\footnotetext{
${ }^{1}$ Dr hab. Leszek Pawlikowicz, prof. UR, Katedra Nauk Historyczno i Teoretyczno Prawnych Uniwersytetu Rzeszowskiego, Wydział Prawa i Administracji, ul. Grunwaldzka 13, 35-068 Rzeszów, autor korespondencyjny; e-mail: pawlikowicz69@interia.pl.

Leszek Pawlikowicz, DSc, PhD, Associate Prof., Department of Historical and Theoretic Legal Science of the University of Rzeszów, ul. Grunwaldzka 13, 35-068 Rzeszów, corresponding author; e-mail: pawlikowicz69@interia.pl.

${ }^{2}$ Dr Krzysztof Surowiec, Katedra Nauk Humanistycznych, Wydział Zarządzania Politechniki Rzeszowskiej im. Ignacego Łukasiewicza, ul. Podkarpacka 1, 35-082 Rzeszów; e-mail: ks@prz.edu.pl. Krzysztof Surowiec, PhD, Department of Humanities, Faculty of Management, Rzeszów University of Technology Ignacy Łukasiewicz, ul. Podkarpacka 1, 35-082 Rzeszów; e-mail: ks@prz.edu.pl.
} 


\section{WSTĘP}

Z perspektywy ponad czterech lat nie ulega najmniejszej wątpliwości, że tzw. kryzys ukraiński, który - poprzez aneksję Krymu i zagarnięcie dwóch obwodów Ukrainy przez Rosję lub wspierane przez nią prorosyjskie formacje zbrojne w 2014 roku - doprowadził w rezultacie do utraty przez ten kraj integralności terytorialnej, nie był jedynie epizodem w postzimnowojennych, generalnie dobrych, relacjach pomiędzy Rosją a szeroko rozumianymi krajami Zachodu, ale stanowił zasadniczą cezurę w całej ich dotychczasowej 25-letniej historii, skutkując zarazem wszczęciem tzw. nowej zimnej wojny ${ }^{3}$.

W ramach nowego etapu relacji państw NATO z Rosją (będącego rezultatem wyżej wymienionego kryzysu) ${ }^{4}$ w latach 2014-2018 wzrosła nie tylko geopolityczna rola wschodniej flanki sojuszu, zwłaszcza krajów bezpośrednio graniczących z FR, ale nastąpiły ponadto znacznie mniej zauważalne, choć nie mniej istotne zmiany w zakresie udziału państw bałtyckich i Polski w ogólnym potencjale ekonomiczno-militarnym Paktu Północnoatlantyckiego, które - jak dotąd - nie były przedmiotem otwartych analiz przeprowadzonych w oparciu o dane pozyskane z jawnych źródeł o uznanej renomie. Celem niniejszego artykułu jest zniwelowanie luki informacyjnej w tym zakresie oraz określenie skali owych zmian, jak również ich bezpośrednich skutków.

\section{PODSTAWOWE ASPEKTY POŁOŻENIA GEOPOLITYCZNEGO PAŃSTW BAŁTYCKICH I POLSKI W RAMACH NATO W LATACH 2014-2018}

W chwili aneksji Krymu i rozpoczęcia sterowanej z Kremla rebelii we wschodniej Ukrainie (w lutym 2014 roku) w skład NATO wchodziło ogółem 28 państw, w tym 26 w Europie. Spośród nich: jedno państwo europejskie - Islandia - nigdy nie utrzymywała własnych sił zbrojnych, a dwa pozaeuropejskie kraje sojuszu (Stany Zjednoczone i Kanada) posiadały na starym kontynencie - nader ograniczone liczebnie - własne kontyngenty wojskowe ${ }^{5}$. Do 2018 roku Sojusz Północnoatlantycki poszerzył się jedynie o jedno dodatkowe państwo: Czarnogórę, przyjętą 5 czerwca 2017 roku. Zatem od tej pory liczba państw NATO wzrosła do 29 , w tym 27 europejskich (zob. aneks, rys. 1).

\footnotetext{
${ }^{3}$ Choć wspomnianego określenia użył po raz pierwszy - już w 2008 roku - dziennikarz James Lucas w tytule swojej książki: The New Cold War. The Future of Russia and the Threat to the West (wyd. polskie: Nowa zimna wojna. Jak Kreml zagraża Rosji i Zachodowi ukazało się równolegle w tym samym roku), to jednak dopiero po aneksji Krymu w 2014 roku zaczęto posługiwać się nim na szerszą skalę (mimo, że politycy oficjalnie starają się mówić jedynie o „groźbie” lub „niebezpieczeństwie” powrotu do ,nowej zimnej wojny”).

${ }^{4} \mathrm{O}$ wzmocnieniu tzw. wschodniej flanki NATO zdecydowano w dniach 4-5 września 2014 roku na szczycie paktu w Newport (w Wielkiej Brytanii). Podczas kolejnych szczytów NATO (8-9 lipca 2016 roku w Warszawie oraz 11-12 lipca 2018 roku w Brukseli) potwierdzono i rozszerzono zakres związanych z tym przedsięwzięć. Zob. szerzej: M. Petersson, NATO's Territorial Defense: The Global Approach and the Regional Approach [w:] NATO's Return To Europe: Engaging Ukraine, Russia and Beyound, red. R.R. Moore, D. Coletta, Georgetown University Press, Washington D.C. 2017, s. 100; NATO Summit Brussels, Belgium - 11 \& 12 July 2018, https://www.nato.int/ cps/en/natohq/news_155085.htm (dostęp: 10.09.2018 r.).

${ }^{5}$ Zob. szerzej: The Military Balance 2014, International Institute for Strategic Studies-Routledge, London 2014, s. 39 i nast.; The Military Balance 2018, International Institute for Strategic StudiesRoutledge, London 2018, s. 43 i nast.
} 
Jedynie pięć państw NATO posiada bezpośrednią granicę lądową z Rosją (łącznie 1318 $\mathrm{km}) \mathrm{i}$ - sprzymierzoną z nią politycznie i militarnie - Białorusią (ogółem $1219 \mathrm{~km}$ ). Są to: Norwegia (191 km granicy z Rosją), Polska (łącznie 628 km, z czego 210 km z Rosją i 418 km z Białorusią), Litwa (ogółem 901 km, w tym 261 km z Rosją oraz 640 km z Białorusią), Łotwa (łącznie 493 km, z czego $332 \mathrm{~km} \mathrm{z} \mathrm{Rosją} \mathrm{i} 161 \mathrm{~km} \mathrm{z} \mathrm{Białorusią)} \mathrm{i} \mathrm{Estonia} \mathrm{(324} \mathrm{km}$ z Rosją) ${ }^{6}$. Wszystkie położone są na wschodniej flance sojuszu, przy czym Norwegia zamyka północną część wspomnianej flanki, a cztery pozostałe kraje są od niej znacznie oddalone tworząc zarazem zwarty blok terytorialny w położonej bardziej na południe centralnej części wschodniego pasa granicznego (zob. aneks, rys. 2).

\section{WYBÓR PARAMETRÓW PORÓWNAWCZYCH}

Z uwagi na fakt, iż do szczegółowego porównania szerokiego zakresu parametrów potencjału państw bałtyckich i Polski wobec całego potencjału Paktu Północnoatlantyckiego oraz ewolucji owego stosunku sił w latach 2014-2018 niezbędne byłoby opracowanie odrębnej monografii uznaliśmy, że na potrzeby niniejszej publikacji najbardziej reprezentatywnymi będzie sześć następujących:

- powierzchnia terytorium;

- liczba ludności;

- poziom Produktu Krajowego Brutto (PKB);

- poziom wydatków wojskowych;

- stan osobowy sił zbrojnych;

- stan wybranych rodzajów uzbrojenia (w rozbiciu na wybrane rodzaje ciężkiego uzbrojenia i sprzętu wojskowego, które w największym stopniu wpływają na wartość bojową sił zbrojnych).

Pierwsze trzy - dotyczące najbardziej podstawowych parametrów terytorialno-demograficznych oraz siły ekonomicznej - mimo że formalnie nie odnoszą się do potencjału militarnego, to jednak w oczywisty sposób go warunkują. Ostatnie trzy czynniki - najlepiej odzwierciedlają siłę wojskową (zarówno w zakresie czynników jakościowych i ilościowych).

\section{ANALIZA}

Po dokonaniu porównań (zob. aneks, tabele 1-10) w obszarze wyżej wspomnianych parametrów udział krajów bałtyckich i Polski w stosunku do potencjału wszystkich krajów NATO wynosił:

- w zakresie powierzchni zajmowanego terytorium 2,030\% w 2014 roku i do 2018 roku spadł do poziomu 2,029\% (co było wyłącznie rezultatem rozszerzenia NATO o terytorium Czarnogóry); w badanym okresie zmiana w odniesieniu do opisywanego parametru wynosiła zatem: $-0,049 \%$;

- w zakresie liczby ludności 4,927\% w 2014 roku, natomiast do 2018 roku spadł do $4,745 \%$ (ze względu na bardzo wysoki poziom emigracji z republik bałtyckich,

\footnotetext{
${ }^{6}$ The CIA World Factbook 2014, Skyhorse Publishing, New York 2014, bez paginacji [EPUB]; The CIA World Factbook 2018-19, Skyhorse Publishing, New York 2018, bez paginacji [EPUB].
} 
w szczególności z Litwy, którą w ciągu wspomnianych czterech lat opuściło aż $24,505 \%$ jej obywateli, co było rekordem w skali wszystkich państw NATO) ${ }^{7}$; $\mathrm{w}$ badanym okresie zmiana $\mathrm{w}$ odniesieniu do opisywanego parametru wynosiła: $-3,836 \%$;

- w zakresie poziomu Produktu Krajowego Brutto liczonego według bieżącej ceny dolara amerykańskiego 1,725\% w 2014 roku i do 2017 roku (dane o PKB są dostępne po zakończeniu roku kalendarzowego, stąd nie było jeszcze możliwości ich pozyskania za rok 2018) spadł do poziomu $1,651 \%$ (czyli zmiana wynosiła: $-4,482 \%$, co wynikało przede wszystkim z aprecjacji bieżącej ceny dolara amerykańskiego wobec euro i pozostałych walut narodowych, nie zaś realnego spadku PKB, gdyż wskaźnik ten mierzony w walutach narodowych krajów bałtyckich i Polski był dodatni i wahał się dla wszystkich czterech krajów w podobnym przedziale wynoszącym od $+13,714 \%$ do $+16,372 \%)$;

- w zakresie wysokości wydatków wojskowych liczonych według definicji NATO w oparciu o bieżącą cenę dolara amerykańskiego 1,203\% w 2014 roku, natomiast do 2017 roku wzrósł (mimo aprecjacji bieżącej ceny dolara amerykańskiego w stosunku do miejscowych walut narodowych) do $1,277 \%$; w badanym okresie zmiana w odniesieniu do opisywanego parametru wynosiła zatem: $+7,771 \%$ (największą dynamikę wzrostu odnotowano pod tym względem na Litwie: $+90,632 \%$ oraz na Łotwie: $+80,546 \%$, a z kolei w przypadku wydatków wojskowych liczonych w oparciu o bieżącą wartość miejscowych walut dynamika wzrostu była jeszcze wyższa i wynosiła na Litwie: $+124,845 \%$, a na Łotwie: $+112,670 \%$, co stawiało wspomniane państwa w pozycji absolutnych liderów w całym Pakcie Północnoatlantyckim pod względem skali wzrostu wydatków wojskowych za lata 2014-2017);

- w zakresie stanu osobowego całości sił zbrojnych 3,408\% w styczniu 2014 roku i do stycznia 2018 roku wzrósł do poziomu 4,218\%; w badanym okresie zmiana w odniesieniu do opisywanego parametru wynosiła: $+23,768 \%$ (ponownie największą dynamikę wzrostu odnotowano pod tym względem na Litwie: $+55,508 \%$, co także i w tym przypadku stanowiło rekord w skali całego NATO), a wśród rodzajów sił zbrojnych wspomnianych czterech krajów największy udział i zarazem największą dynamikę wzrostu odnotowały siły lądowe (3,090\% w styczniu 2014 roku do 4,620\% w styczniu 2018 roku, co stanowiło wzrost o: $+49,515 \%$ ), najmniejszy natomiast siły morskie (1,504\% w styczniu 2014 roku do $1,578 \%$ w styczniu 2018 roku, co było równoznaczne z wzrostem o: $+4,920 \%)$;

- w zakresie liczby podstawowych czołgów bojowych 5,695\% w styczniu 2014 roku (ze względu na relatywnie wysoki poziom ,upancernienia” Wojska Polskiego), natomiast do stycznia 2018 roku wzrósł do 6,096\% (wzrost o: $+7,041 \%$ ), liczby dział i moździerzy o kalibrze ponad $150 \mathrm{~mm}$ 2,152\% w styczniu 2014 roku (również z uwagi na wkład Sił Zbrojnych RP) i do stycznia 2018 roku wzrósł do 2,661\% (wzrost o: $+23,652 \%$ ), liczby samolotów bojowych z napędem odrzutowym $1,834 \%$ w styczniu 2014 roku (wynikający z absolutnego braku takich samolotów w krajach bałtyckich i relatywnie ich niskiej liczby w Siłach Powietrznych RP), a do stycznia

\footnotetext{
${ }^{7}$ Wspomniane zjawisko emigracji miało charakter ekonomiczny i było związane z możliwością podejmowania pracy w państwach zachodniej części kontynentu po rozszerzeniu Unii Europejskiej (o wszystkie cztery opisywane kraje) począwszy od maja 2004 roku.
} 
2018 roku (głównie ze względu na brak analogicznych śmigłowców w krajach bałtyckich) spadł do 1,696\% (zmiana o: $-8,137 \%$ ), liczby śmigłowców przeciwpancernych 2,220\% w styczniu 2014 roku i do stycznia 2018 roku wzrósł do 2,383\% (wzrost o: $+7,342 \%$ ), liczby dużych okrętów nawodnych (lotniskowców, krążowników, niszczycieli i fregat powyżej 2.000 ton pełnej wyporności) 0,733\% w styczniu 2014 roku (z uwagi na tradycyjnie niewielką ich liczbę w Marynarce Wojennej RP), a do stycznia 2018 roku wzrósł nieznacznie do $0,772 \%$ (wzrost o: $+5,320 \%$ ), liczby okrętów podwodnych $3,356 \%$ w styczniu 2014 roku i do stycznia 2018 roku pozostał na tym samym poziomie.

Należy zatem zauważyć, że w 2014 roku największy wkład państw bałtyckich i Polski do ogólnego potencjału NATO wynosił (według wielkości udziału):

- $-5,695 \%$ w odniesieniu do liczby podstawowych czołgów bojowych;

- $-4,927 \%$ w odniesieniu do liczby ludności;

- $-3,408 \%$ w odniesieniu do stanu osobowego całości sił zbrojnych;

- $-3,356 \%$ w odniesieniu do liczby okrętów podwodnych;

- $-2,220 \%$ w odniesieniu do liczby śmigłowców przeciwpancernych;

- $-2,152 \%$ w odniesieniu do liczby dział i moździerzy o kalibrze ponad $150 \mathrm{~mm}$;

- $-2,030 \%$ w odniesieniu do powierzchni zajmowanego terytorium;

- $-1,834 \%$ w odniesieniu do liczby samolotów bojowych z napędem odrzutowym;

- $-1,725 \%$ w odniesieniu do poziomu Produktu Krajowego Brutto liczonego według bieżącej ceny dolara amerykańskiego;

- $-1,203 \%$ w odniesieniu do wysokości wydatków wojskowych liczonych według definicji NATO w oparciu o bieżącą cenę dolara amerykańskiego;

- $-0,733 \%$ w odniesieniu do liczby dużych okrętów nawodnych (lotniskowców, krążowników, niszczycieli i fregat powyżej 2000 ton pełnej wyporności).

Z kolei w 2018 roku (wyjątkowo w 2017 roku dla danych odnoszących się do poziomu PKB i wydatków wojskowych) wkład państw bałtyckich i Polski do ogólnego potencjału NATO wynosił (według wielkości udziału):

- $-6,096 \%$ w odniesieniu do liczby podstawowych czołgów bojowych;

- $-4,745 \%$ w odniesieniu do liczby ludności;

- $-4,218 \%$ w odniesieniu do stanu osobowego całości sił zbrojnych;

- $-3,356 \%$ w odniesieniu do liczby okrętów podwodnych;

- $-2,661 \%$ w odniesieniu do liczby dział i moździerzy o kalibrze ponad $150 \mathrm{~mm}$;

- $-2,383 \%$ w odniesieniu do liczby śmigłowców przeciwpancernych;

- $-2,029 \%$ w odniesieniu do powierzchni zajmowanego terytorium;

- $-1,696 \%$ w odniesieniu do liczby samolotów bojowych z napędem odrzutowym;

- $-1,651 \%$ w odniesieniu do poziomu Produktu Krajowego Brutto liczonego według bieżącej ceny dolara amerykańskiego;

- $-1,277 \%$ w odniesieniu do wysokości wydatków wojskowych liczonych według definicji NATO w oparciu o bieżącą cenę dolara amerykańskiego; 
- $-0,772 \%$ w odniesieniu do liczby dużych okrętów nawodnych (lotniskowców, krążowników, niszczycieli i fregat powyżej 2000 ton pełnej wyporności).

Zatem największy wzrost wkładu państw bałtyckich i Polski do ogólnego potencjału NATO w latach 2017-2018 (wyjątkowo w 2017 roku dla danych odnoszących się do poziomu PKB i wydatków wojskowych) wynosił (według wielkości udziału):

- $+23,768 \%$ w odniesieniu do stanu osobowego całości sił zbrojnych;

- $+23,652 \%$ w odniesieniu do liczby dział i moździerzy o kalibrze ponad $150 \mathrm{~mm}$;

- $+7,771 \%$ w odniesieniu do wysokości wydatków wojskowych liczonych według definicji NATO w oparciu o bieżącą cenę dolara amerykańskiego;

- $+7,342 \%$ w odniesieniu do liczby śmigłowców przeciwpancernych;

- $+7,041 \%$ w odniesieniu do liczby podstawowych czołgów bojowych;

- $+5,320 \%$ w odniesieniu do liczby dużych okrętów nawodnych (lotniskowców, krążowników, niszczycieli i fregat powyżej 2000 ton pełnej wyporności);

- $\pm 0 \%$ w odniesieniu do liczby okrętów podwodnych;

- $-0,049 \%$ w odniesieniu do powierzchni zajmowanego terytorium;

- $-3,836 \%$ w odniesieniu do liczby ludności;

- $-4,482 \%$ w odniesieniu do poziomu Produktu Krajowego Brutto liczonego według bieżącej ceny dolara amerykańskiego;

- $-8,137 \%$ w odniesieniu do liczby samolotów bojowych z napędem odrzutowym.

Warto przypomnieć, że wzrost wspomnianych udziałów w analizowanym okresie nie zawsze wynikał ze zwiększenia wielkości parametru w państwach bałtyckich i Polsce, gdyż często był rezultatem zmniejszenia wielkości tegoż parametru w ogólnym potencjale NATO (np. poprzez zmniejszenie w analizowanym okresie czasu stanu osobowego całości sił zbrojnych).

\section{WNIOSKI}

Ze względu na własne położenie geopolityczne, a częściowo także z uwagi na zobowiązania wynikające z członkostwa w Pakcie Północnoatlantyckim - państwa bałtyckie i Polska w okresie ponad czterech lat od wybuchu kryzysu ukraińskiego relatywnie wzmocniły swój udział w potencjale militarnym (wszystkich krajów) NATO. Dotyczyło to w szczególności: stanu osobowego sił zbrojnych oraz wysokości wydatków wojskowych, a w zakresie ciężkiego uzbrojenia: liczby dział i moździerzy o największym kalibrze.

Choć, największą dynamikę w pierwszych dwóch parametrach wykazywała Litwa (co zarazem umiejscawiało ją pod tym względem na pierwszym miejscu w całym Pakcie Północnoatlantyckim), to - tradycyjnie, tak jak przed 2014 rokiem - najwyższe stany osobowe sił zbrojnych nadal utrzymywała Polska, a najwyższy udział wydatków wojskowych w stosunku do PKB - Estonia. Jednak największy wkład do potencjału NATO ze strony analizowanych państw dotyczył relatywnie dużej liczby podstawowych czołgów bojowych (wyłącznie ze względu na wysoki stopień ,upancernienia” Wojska Polskiego).

Relatywnie słabym punktem w potencjale militarnym badanych krajów jest natomiast niski udział samolotów bojowych z napędem odrzutowym, a zwłaszcza brak jakichkolwiek planów związanych z zakupem myśliwców V generacji. 


\section{LITERATURA}

1. Defence Expenditure of NATO Countries (2010-2017), North Atlantic Treaty Organisation COMMUNIQUE PR/CP(2018)16, Bruxelles 15 March 2018.

2. Jane's Fighting Ships 2015-2016 (red. S. Sanders), IHS-Janes Information Group, Surrey 2015.

3. Lucas Edward, Nowa zimna wojna. Jak Kreml zagraża Rosji i Zachodowi, Dom Wydawniczy „Rebis”, Poznań 2008.

4. Petersson Magnus, NATO's Territorial Defense: The Global Approach and the Regional Approach [w:] NATO's Return To Europe: Engaging Ukraine, Russia and Beyound (red. Moore Rebecca R., Coletta Damon), Georgetown University Press, Washington D.C. 2017, s. 97-112.

5. Lucas Edward, The New Cold War. The Future of Russia and the Threat to the West, Palgrave Macmillan, New York 2008.

6. Rocznik statystyczny Rzeczypospolitej Polskiej 2015, Główny Urząd Statystyczny, Warszawa 2015.

7. The CIA World Factbook 2015, Skyhorse Publishing, New York 2014, [EPUB].

8. The CIA World Factbook 2018-19, Skyhorse Publishing, New York 2018 [EPUB].

9. The Military Balance 2014, International Institute for Strategic Studies-Routledge, London 2014.

10. The Military Balance 2018, International Institute for Strategic Studies-Routledge, London 2018.

\section{NETOGRAFIA}

1. Gross Domestic Product at market proces, Eurostat, http://ec.europa.eu/eurostat/tgm/refreshTableAction. do?tab=table \&plugin $=1 \&$ pcode $=$ tec00001\&language $=e n \quad($ dostęp: 10.07 . 2018 r.).

2. NATO Summit Brussels, Belgium - 11 \& 12 July 2018, https://www.nato.int/cps/en/ natohq/news_155085.htm (dostęp: 10.09.2018 r.).

3. World Development Indicators, World Bank Data, http://databank.worldbank.org/data/reports.aspx? source=2\&type=metadata\&series=NY.GDP.MKTP.CD\# (dostęp: 10.07.2018 r.). 


\section{ANEKSY}

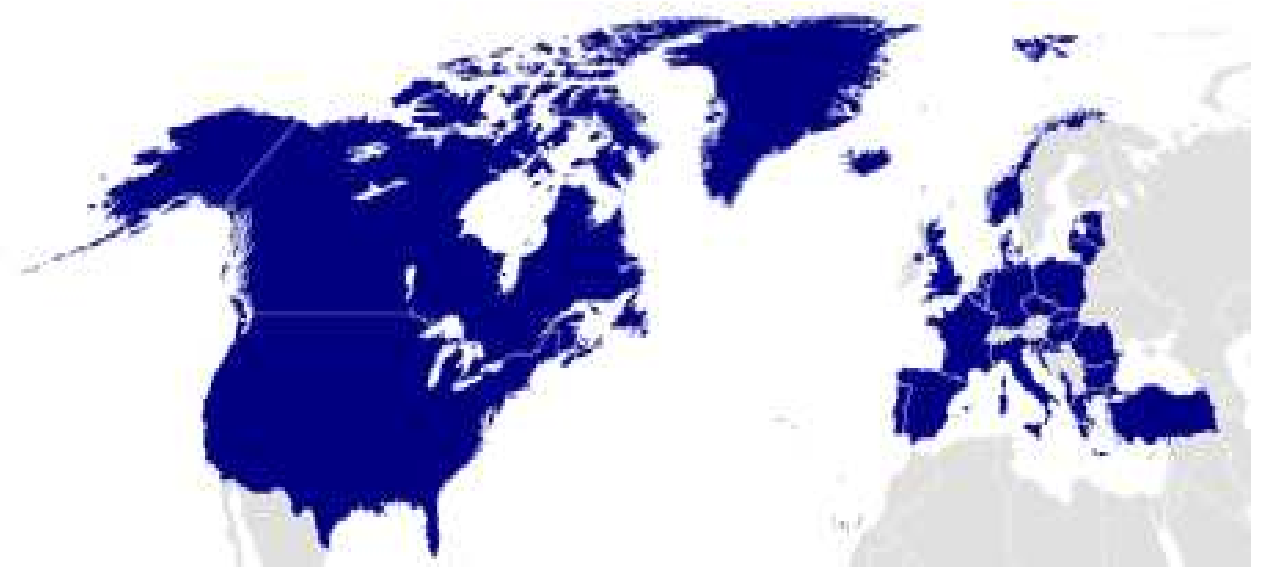

Rys. 1. Państwa NATO w 2018 roku

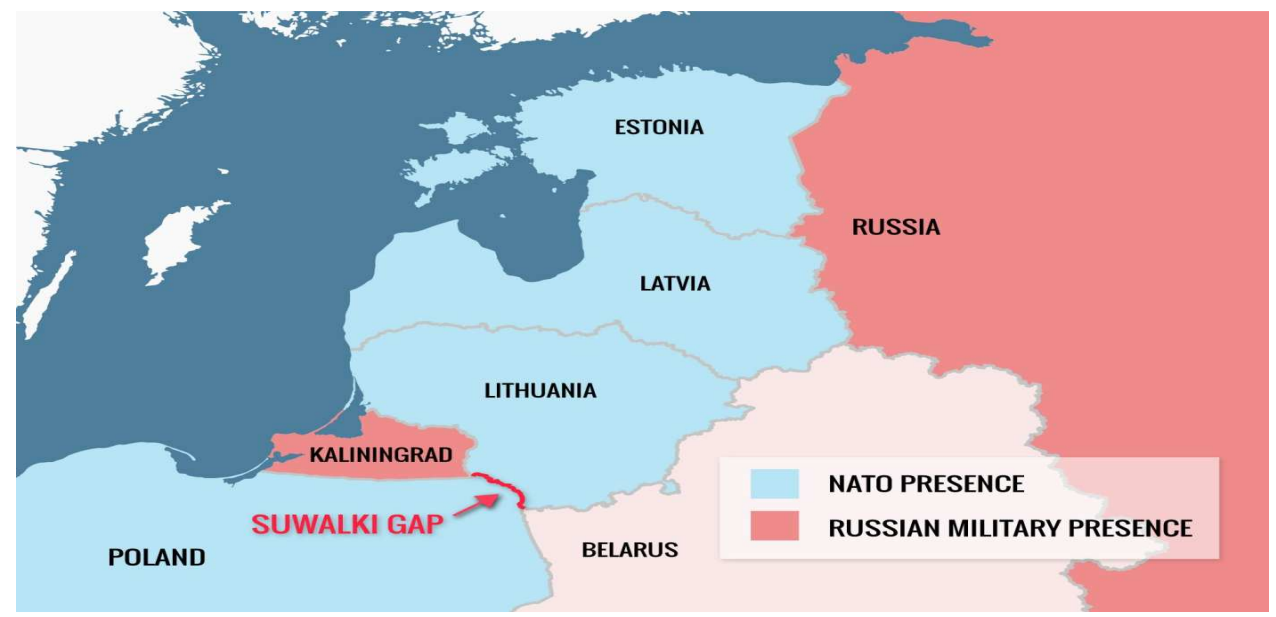

Rys. 2. Północny sektor wschodniej flanki NATO 
Tabela 1. Potencjał terytorialny i demograficzny państw NATO w 2014 oraz w 2018 roku

\begin{tabular}{|l|c|c|c|c|}
\hline \multirow{2}{*}{\multicolumn{1}{|c|}{ Państwa NATO }} & \multicolumn{2}{|c|}{$\mathbf{2 0 1 4}$} & \multicolumn{2}{c|}{$\mathbf{2 0 1 8}$} \\
\cline { 2 - 5 } & $\begin{array}{c}\text { Powierzchnia } \\
\text { (tys. km }{ }^{\text {) }}\end{array}$ & Ludność & $\begin{array}{c}\text { Powierzchnia } \\
\text { (tys. km })^{\mathbf{}}\end{array}$ & Ludność \\
\hline Albania & 27,748 & 3.011 .405 & 27,748 & 3.047 .987 \\
\hline Belgia & 30,528 & 10.444 .268 & 30,528 & 11.491 .346 \\
\hline Bułgaria & 110,879 & 6.981 .642 & 110,879 & 7.101 .510 \\
\hline Chorwacja & 56,594 & 4.475 .611 & 56,594 & 4.292 .095 \\
\hline Czarnogóra & \multicolumn{2}{|c|}{ nie należała do NATO } & 13,812 & 642.550 \\
\hline Czechy & 78,867 & 10.162 .921 & 78,867 & 10.674 .723 \\
\hline Dania & 43,094 & 5.556 .452 & 43,094 & 5.605 .948 \\
\hline Estonia & 45,228 & 1.266 .375 & 45,228 & 1.251 .581 \\
\hline Francja & 551,500 & 65.951 .611 & 551,500 & 67.106 .161 \\
\hline Grecja & 131,957 & 10.772 .967 & 131,957 & 10.768 .477 \\
\hline Hiszpania & 505,370 & 47.370 .542 & 505,370 & 48.958 .159 \\
\hline Holandia & 41,543 & 16.805 .037 & 41,543 & 17.084 .719 \\
\hline Islandia & 103,000 & 315.281 & 103,000 & 339.747 \\
\hline Kanada & $9.984,670$ & 34.568 .211 & $9.984,670$ & 35.623 .680 \\
\hline Litwa & 65,300 & 3.515 .858 & 65,300 & 2.823 .859 \\
\hline Lotwa & 64,589 & 2.178 .443 & 64,589 & 1.944 .643 \\
\hline Luksemburg & 2,586 & 514.862 & 2,586 & 594.130 \\
\hline Niemcy & 357,022 & 81.147 .265 & 357,022 & 80.594 .017 \\
\hline Norwegia & 323,802 & 4.722 .701 & 323,802 & 5.320 .045 \\
\hline Polska & 312,685 & 38.383 .809 & 312,685 & 38.476 .269 \\
\hline Portugalia & 92,080 & 10.799 .270 & 92,080 & 10.839 .514 \\
\hline Rumunia & 238,391 & 21.790 .479 & 238,391 & 21.529 .967 \\
\hline Słowacja & 49,035 & 5.488 .339 & 49,035 & 5.445 .829 \\
\hline Słowenia & 20,273 & 1.992 .690 & 20,273 & 1.972 .126 \\
\hline Stany Zjednoczone & $9.372,610$ & 316.668 .567 & $9.372,610$ & 326.625 .791 \\
\hline Turcja & 783,562 & 80.694 .485 & 783,562 & 80.845 .215 \\
\hline Węgry & 93,028 & 9.939 .470 & 93,028 & 9.850 .845 \\
\hline Wielka Brytania & 243,610 & 63.395 .574 & 243,610 & 64.769 .452 \\
\hline Włochy & 301,340 & 61.482 .297 & 301,340 & 62.137 .802 \\
\hline Ogółem & $\mathbf{2 4 . 0 3 0 , 8 9 1}$ & $\mathbf{9 2 0 . 3 9 6 . 4 3 2}$ & $\mathbf{2 4 . 0 4 4 , 7 0 3}$ & $\mathbf{9 3 7 . 7 5 8 . 1 8 7}$ \\
\hline Zmiana w \% & $\mathbf{1 0 0 , 0 0 0}$ & $\mathbf{1 0 0 , 0 0 0}$ & $\mathbf{1 0 0 , 0 6}$ & $\mathbf{1 0 1 , 8 9}$ \\
\hline
\end{tabular}

Źródła: opracowanie własne na podstawie The CIA World Factbook 2015, Skyhorse Publishing, New York 2014, [EPUB]; The CIA World Factbook 2018-19, Skyhorse Publishing, New York 2018, bez paginacji [EPUB]; The Military Balance 2014, International Institute for Strategic Studies-Routledge, London 2014, s. 39 i nast.; The Military Balance 2018, International Institute for Strategic StudiesRoutledge, London 2018, s. 43 i nast. 
Tabela 2. Potencjał terytorialny i demograficzny państw bałtyckich oraz Polski w 2014 i w 2018 roku

\begin{tabular}{|l|c|c|c|c|}
\hline $\begin{array}{c}\text { Państwa } \\
\text { NATO }\end{array}$ & $\begin{array}{c}\text { Powierzchnia } \\
\text { w latach } \\
\mathbf{2 0 1 4 - 2 0 1 8} \\
\text { (tys. km²) }\end{array}$ & $\begin{array}{c}\text { Ludność } \\
\text { w 2014 r. }\end{array}$ & $\begin{array}{c}\text { Ludność } \\
\text { w 2018 r. }\end{array}$ & $\begin{array}{c}\text { Wzrost } \\
\text { ludności } \\
\text { w latach } \\
\mathbf{2 0 1 4 - 2 0 1 8} \\
\text { (\%) }\end{array}$ \\
\hline Estonia & 45,228 & 1.266 .375 & 1.251 .581 & $-1,182$ \\
\hline Litwa & 65,300 & 3.515 .858 & 2.823 .859 & $-24,505$ \\
\hline Lotwa & 64,589 & 2.178 .443 & 1.944 .643 & $-12,023$ \\
\hline Polska & 312,685 & 38.383 .809 & 38.476 .269 & $+0,241$ \\
\hline Ogółem & $\mathbf{4 8 7 , 8 0 2}$ & $\mathbf{4 5 . 3 4 4 . 4 8 5}$ & $\mathbf{4 4 . 4 9 6 . 3 5 2}$ & $\mathbf{- 1 , 9 0 6}$ \\
\hline $\begin{array}{l}\text { Udział w całości } \\
\text { potencjału NATO w \% }\end{array}$ & $\begin{array}{c}\mathbf{2 , 0 3 0}(\mathbf{2 0 1 4} \text { r.) } \\
\mathbf{2 , 0 2 9}(\mathbf{w} \mathbf{2 0 1 8} \text { r.) }\end{array}$ & $\mathbf{4 , 9 2 7}$ & $\mathbf{4 , 7 4 5}$ & \\
\hline
\end{tabular}

Źródła: opracowanie własne na podstawie The CIA World Factbook 2015..., bez paginacji [EPUB]; The CIA World Factbook 2018-19..., [EPUB]; The Military Balance 2014..., s. 39 i nast.; The Military Balance $2018 \ldots$, s. 43 i nast.

Tabela 3. Poziom PKB i wydatków wojskowych państw NATO w 2014 i 2017 roku*

\begin{tabular}{|c|c|c|c|c|}
\hline \multirow[b]{2}{*}{ Państwa NATO } & \multicolumn{2}{|c|}{2014} & \multicolumn{2}{|c|}{2017} \\
\hline & $\begin{array}{c}\text { PKB } \\
\text { wg. bieżącej } \\
\text { wartości \$ } \\
(\text { mld \$) }\end{array}$ & $\begin{array}{l}\text { Wydatki wojskowe } \\
\text { wg. definicji NATO } \\
(\text { mld \$) }\end{array}$ & $\begin{array}{c}\text { PKB } \\
\text { wg. bieżącej } \\
\text { wartości \$ } \\
(\text { mld \$) }\end{array}$ & $\begin{array}{l}\text { Wydatki wojskowe } \\
\text { wg. definicji NATO } \\
(\text { mld \$) }\end{array}$ \\
\hline Albania & 13,228 & 0,178 & 13,039 & 0,145 \\
\hline Belgia & 530,771 & 5,192 & 492,681 & 4,458 \\
\hline Bułgaria & 56,732 & 0,747 & 56,832 & 0,871 \\
\hline Chorwacja & 57,630 & 0,805 & 54,849 & 0,690 \\
\hline Czarnogóra & \multicolumn{2}{|c|}{ nie należała do NATO } & 4,774 & 0,074 \\
\hline Czechy & 207,818 & 1,975 & 215,726 & 2,249 \\
\hline Dania & 352,994 & 4,056 & 324,872 & 3,802 \\
\hline Estonia & 26,225 & 0,513 & 25,921 & 0,538 \\
\hline Francja & $2.852,166$ & 51,940 & $2.582,501$ & 45,927 \\
\hline Grecja & 237,030 & 5,226 & 200,288 & 4,737 \\
\hline Hiszpania & $1.376,911$ & 12,614 & $1.311,320$ & 12,074 \\
\hline Holandia & 879,635 & 10,332 & 826,200 & 9,765 \\
\hline Islandia & 17,304 & 0 & 23,909 & 0 \\
\hline Kanada & $1.799,269$ & 18,150 & $1.653,043$ & 21,275 \\
\hline Litwa & 48,516 & 0,427 & 47,168 & 0,814 \\
\hline Luksemburg & 66,327 & 0,253 & 62,404 & 0,288 \\
\hline Lotwa & 31,335 & 0,293 & 30,264 & 0,529 \\
\hline Niemcy & $3.890,607$ & 46,102 & $3.677,439$ & 45,472 \\
\hline Norwegia & 499,339 & 7,336 & 398,832 & 6,698 \\
\hline Polska & 545,180 & 10,104 & 524,510 & 10,337 \\
\hline Portugalia & 229,630 & 3,003 & 217,571 & 2,824 \\
\hline Rumunia & 199,493 & 2,692 & 211,803 & 3,658 \\
\hline
\end{tabular}


Tabela 3 (cd.). Poziom PKB i wydatków wojskowych państw NATO w 2014 i 2017 roku*

\begin{tabular}{|c|c|c|c|c|}
\hline \multirow[b]{2}{*}{ Państwa NATO } & \multicolumn{2}{|c|}{2014} & \multicolumn{2}{|c|}{2017} \\
\hline & $\begin{array}{c}\text { PKB } \\
\text { wg. bieżącej } \\
\text { wartości \$ } \\
(\text { mld \$) }\end{array}$ & $\begin{array}{c}\text { Wydatki wojskowe } \\
\text { wg. definicji NATO } \\
\text { (mld \$) }\end{array}$ & $\begin{array}{c}\text { PKB } \\
\text { wg. bieżącej } \\
\text { wartości \$ } \\
(\text { mld \$) }\end{array}$ & $\begin{array}{c}\text { Wydatki wojskowe } \\
\text { wg. definicji NATO } \\
\text { (mld \$) }\end{array}$ \\
\hline Słowacja & 100,948 & 0,997 & 95,769 & 1,129 \\
\hline Słowenia & 49,905 & 0,486 & 48,770 & 0,478 \\
\hline Stany Zjednoczone & $17.427,609$ & 653,942 & $19.390,604$ & 685,957 \\
\hline Turcja & 934,186 & 13,583 & 851,102 & 12,118 \\
\hline Węgry & 140,118 & 1,210 & 139,135 & 1,464 \\
\hline Wielka Brytania & $3.022,828$ & 65,690 & $2.622,434$ & 55,237 \\
\hline Włochy & $2.151,733$ & 24,448 & $1.934,798$ & 23,369 \\
\hline Ogółem & $37.745,467$ & 942,294 & $38.038,558$ & 956,977 \\
\hline Zmiana w \% & 100,000 & 100,000 & 100,776 & 101,558 \\
\hline
\end{tabular}

* W dostępnych źródłach nie ma jeszcze danych o PKB za rok 2018.

Źródła: opracowanie własne na podstawie World Developmnent Indicators, World Bank Data (http://databank. worldbank.org/data/ reports.aspx?source=2\&type=metadata\&series=NY.GDP. MKTP.CD\#) - dostęp 10.07.2018 r.; Defence Expenditure of NATO Countries (2010-2017), North Atlantic Treaty Organisation COMMUNIQUE PR/CP(2018)16, Bruxelles 15 March 2018, s. 7.

Tabela 4. Poziom i dynamika wzrostu PKB państw bałtyckich oraz Polski pomiędzy 2014 i 2017 rokiem*

\begin{tabular}{|c|c|c|c|c|c|c|}
\hline \multirow[t]{2}{*}{$\begin{array}{c}\text { Państwa } \\
\text { NATO }\end{array}$} & \multicolumn{2}{|c|}{$\begin{array}{c}\text { PKB } \\
\text { liczone w oparciu } \\
\text { o bieżącą wartość } \\
\text { miejscowych walut } \\
\text { (mld jednostki walutowej) }\end{array}$} & \multirow[t]{2}{*}{$\begin{array}{c}\text { Wzrost w latach } \\
\text { 2014-2017 } \\
\text { wg. bieżącej } \\
\text { wartości } \\
\text { miejscowych } \\
\text { walut }(\%)\end{array}$} & \multicolumn{2}{|c|}{$\begin{array}{c}\text { PKB } \\
\text { liczone w oparciu } \\
\text { o bieżącą wartość \$ } \\
\text { (mld \$) }\end{array}$} & \multirow[t]{2}{*}{$\begin{array}{c}\text { Wzrost } \\
\text { w latach } \\
\text { 2014-2017 } \\
\text { wg. bieżącej } \\
\text { wartości } \\
\$(\%)\end{array}$} \\
\hline & w 2014 r. & w 2017 r. & & w 2014 r. & w 2017 r. & \\
\hline Estonia & $€ \quad 19,766$ & $€ 23,002$ & $+16,372$ & 26,225 & 25,921 & $-1,173$ \\
\hline Litwa & $€ 36,568$ & $€ 41,857$ & $+14,463$ & 48,516 & 47,168 & $-2,858$ \\
\hline Lotwa & $€ 23,618$ & $€ 26,857$ & $+13,714$ & 31,335 & 30,264 & $-3,539$ \\
\hline Polska & zł 1.719,097 & zł $1.982,080$ & $+15,298$ & 545,180 & 524,510 & $-3,941$ \\
\hline Ogółem & & & & 651,256 & 627,863 & \\
\hline Średnia w \% & & & & & & $-3,726$ \\
\hline $\begin{array}{l}\text { Udział } \\
\text { w całości } \\
\text { potencjału } \\
\text { NATO w \% }\end{array}$ & & & & 1,725 & 1,651 & \\
\hline
\end{tabular}

* W dostępnych źródłach nie ma jeszcze danych o PKB za rok 2018.

Źródła: opracowanie własne na podstawie Gross Domestic Product at market proces, Eurostat (http://ec.europa.eu/eurostat/tgm/refreshTable Action.do?tab=table\&plugin=1\&pcode=tec00001\& language=en) - dostęp 10.07.2018 r.; Rocznik statystyczny Rzeczypospolitej Polskiej 2015, Główny Urząd Statystyczny, Warszawa 2015, s. 692; World Developmnent..., (http://databank.worldbank.org/data/reports.aspx ?source $=2$ type $=$ metadata\& series=NY.GDP. MKTP.CD\#) - dostęp 10.07.2018 r. 
Tabela 5. Poziom i dynamika wzrostu wydatków wojskowych państw bałtyckich oraz Polski pomiędzy 2014 i 2017 rokiem*

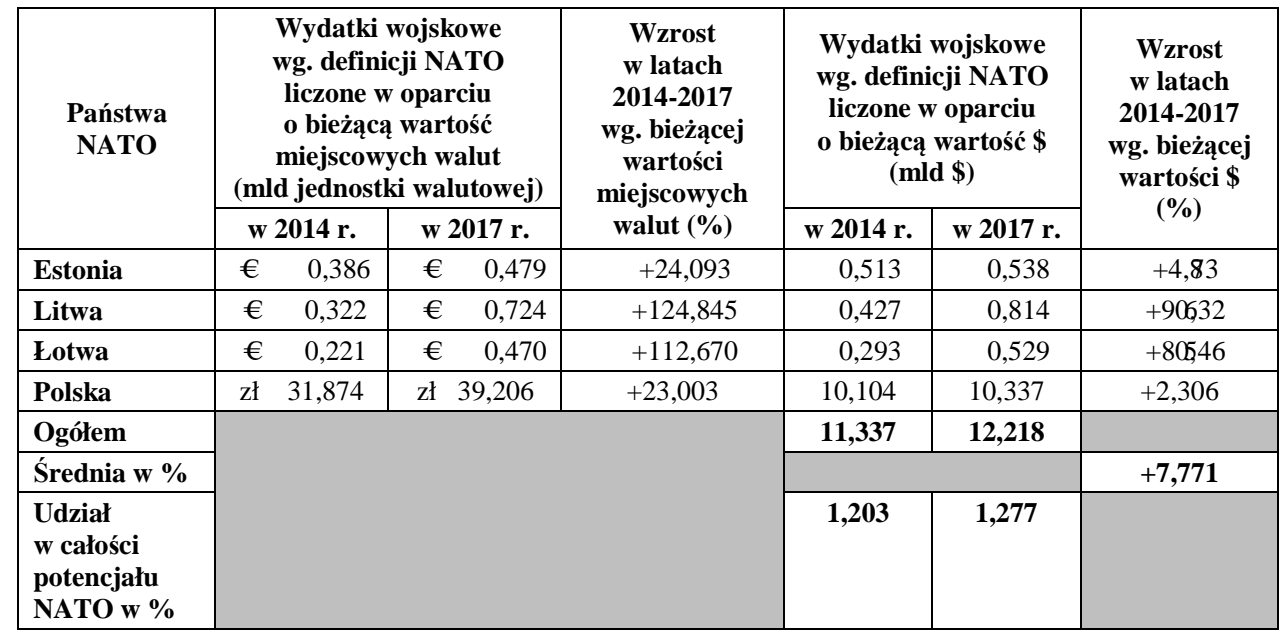

* W dostępnych źródłach nie ma jeszcze danych o PKB za rok 2018.

Źródła: opracowanie własne na podstawie Defence Expenditure of NATO Countries..., s. 6, 7.

Tabela 6. Udział i dynamika wzrostu wydatków wojskowych w PKB państw bałtyckich oraz Polski pomiędzy 2014 i 2017 rokiem*

\begin{tabular}{|l|c|c|c|}
\hline \multirow{2}{*}{$\begin{array}{c}\text { Państwa } \\
\text { NATO }\end{array}$} & \multicolumn{2}{c|}{$\begin{array}{c}\text { Udział wydatków wojskowych } \\
\text { w PKB } \\
\text { (\%) }\end{array}$} & $\begin{array}{c}\text { Wzrost w latach } \\
\mathbf{2 0 1 4 - 2 0 1 7} \\
(\boldsymbol{\%})\end{array}$ \\
\cline { 2 - 3 } & $\mathbf{w ~ 2 0 1 4 ~ r . ~}$ & w 2017 r. & $+6,605$ \\
\hline Estonia & 1,953 & 2,082 & $+96,368$ \\
\hline Litwa & 0,881 & 1,730 & $+86,966$ \\
\hline Łotwa & 0,936 & 1,750 & $+6,688$ \\
\hline Polska & 1,854 & 1,978 & $+\mathbf{3 4 , 0 6 8}$ \\
\hline Średnia w \% & $\mathbf{1 , 4 0 6}$ & $\mathbf{1 , 8 8 5}$ & $\mathbf{+ 0 , 8 0 1}$ \\
\hline Średnia dla ogółu NATO w \% & $\mathbf{2 , 4 9 6}$ & $\mathbf{2 , 5 1 6}$ & \\
\hline
\end{tabular}

Źródła: opracowanie własne na podstawie Gross Domestic Product AT..., Eurostat (http://ec.europa.eu/eurostat/tgm/refreshTableAction.do? tab=table\&plugin=1\&pcode=tec00001\&language=en) - dostęp 10.07.2018 r.; Rocznik statystyczny Rzeczypospolitej Polskiej 2015..., s. 692; Defence Expenditure of NATO Countries..., s. 6, 7. 


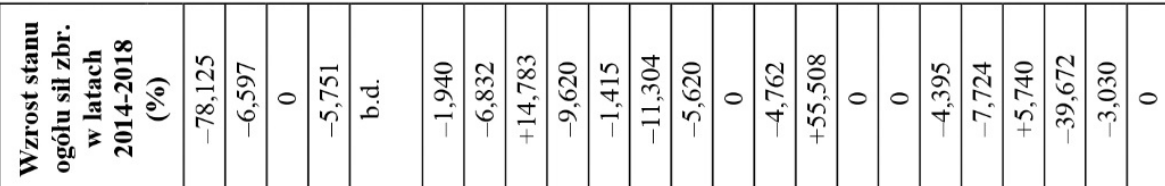

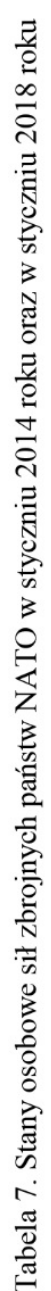

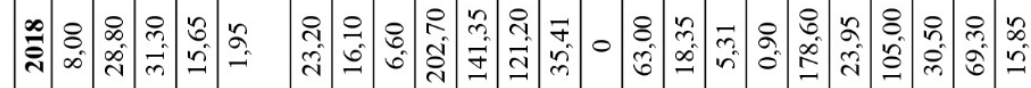

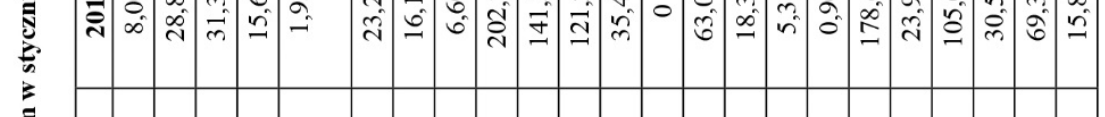

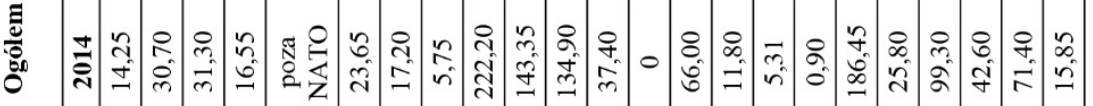

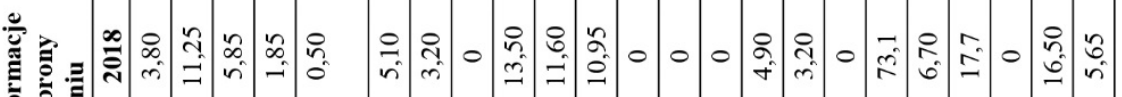

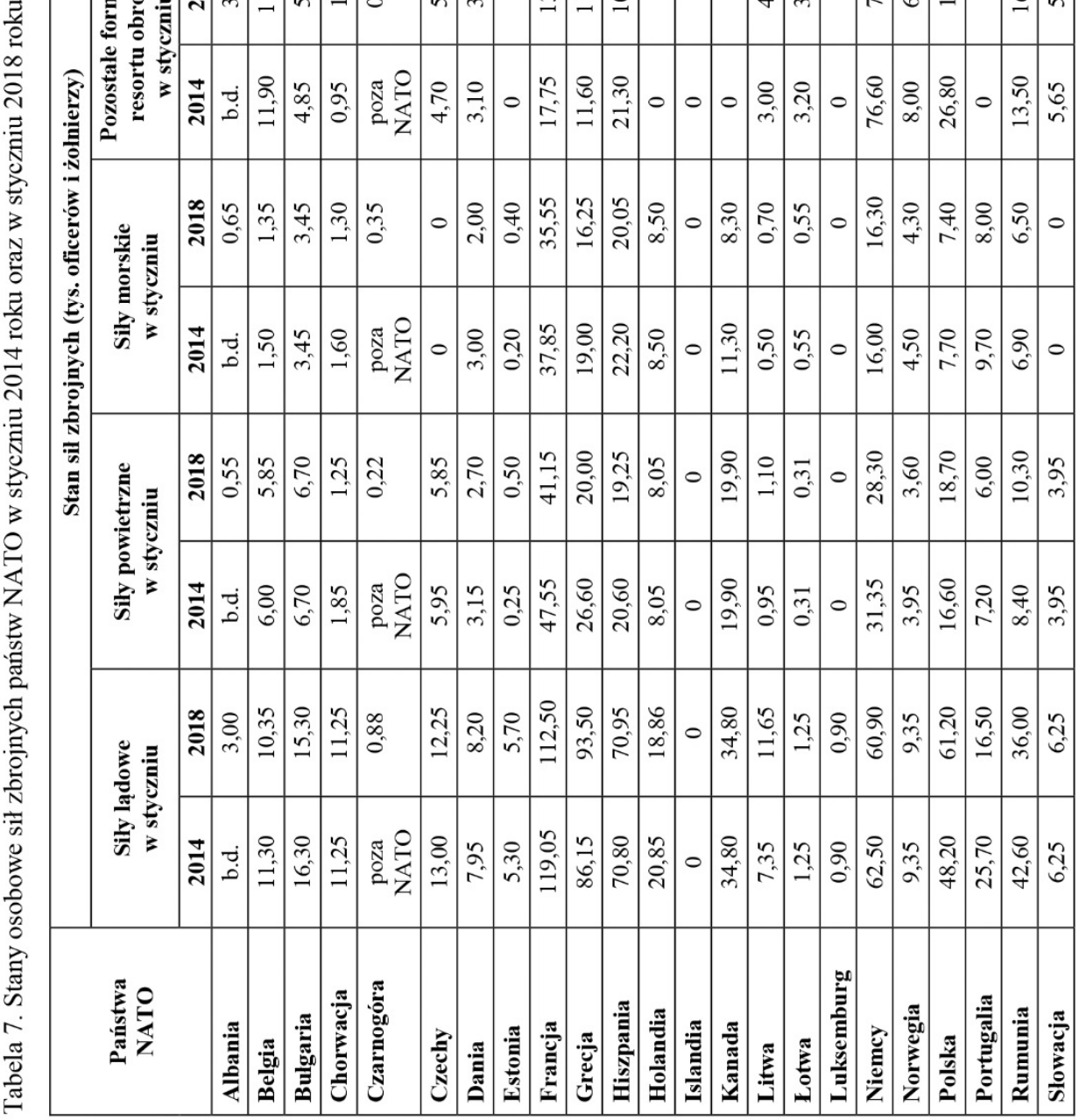




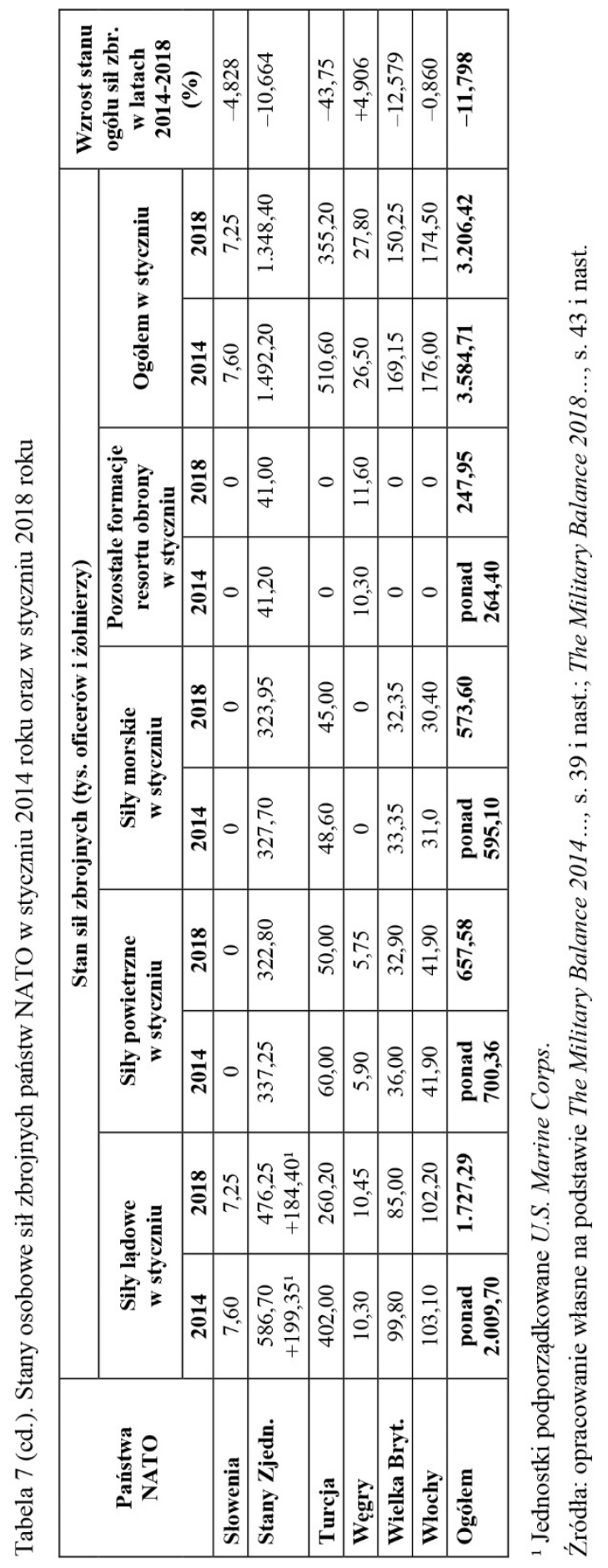




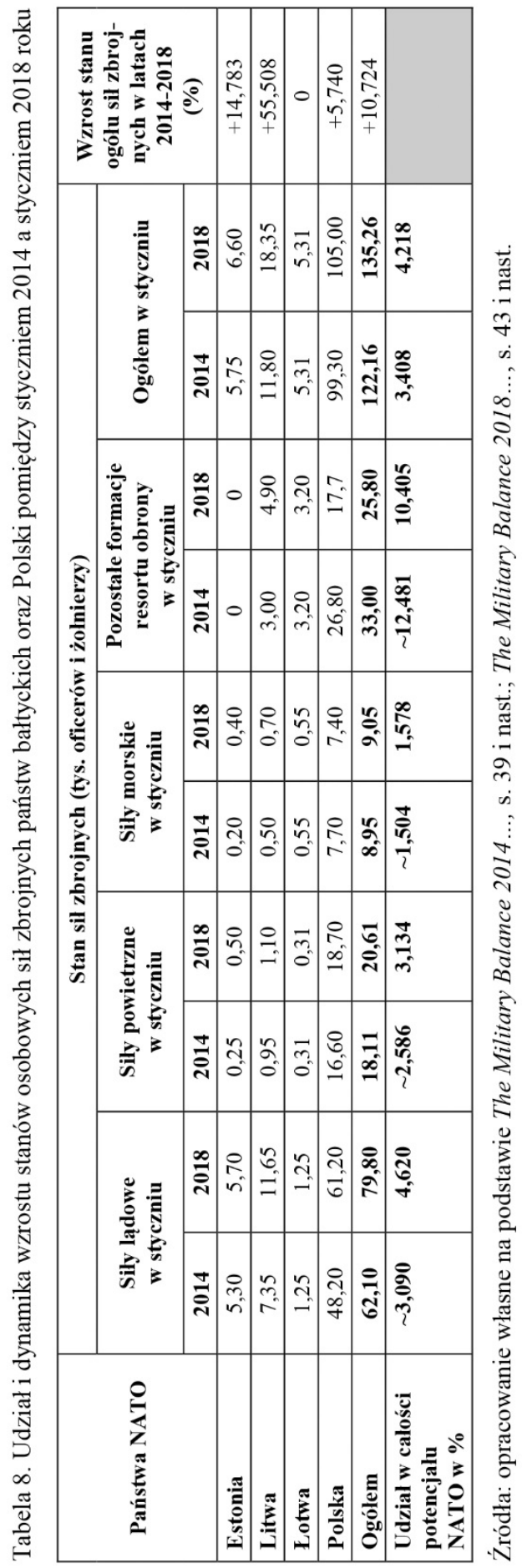




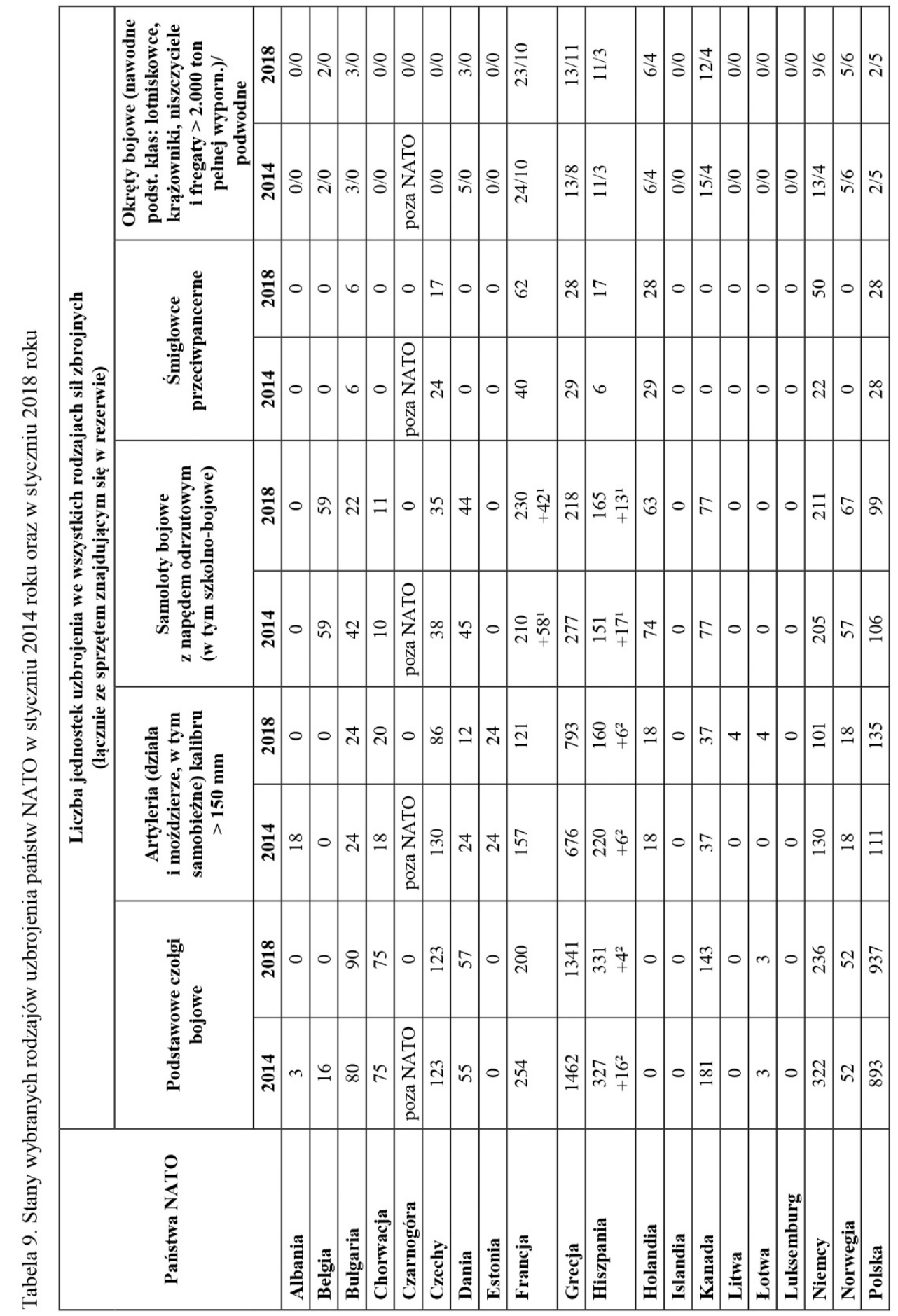




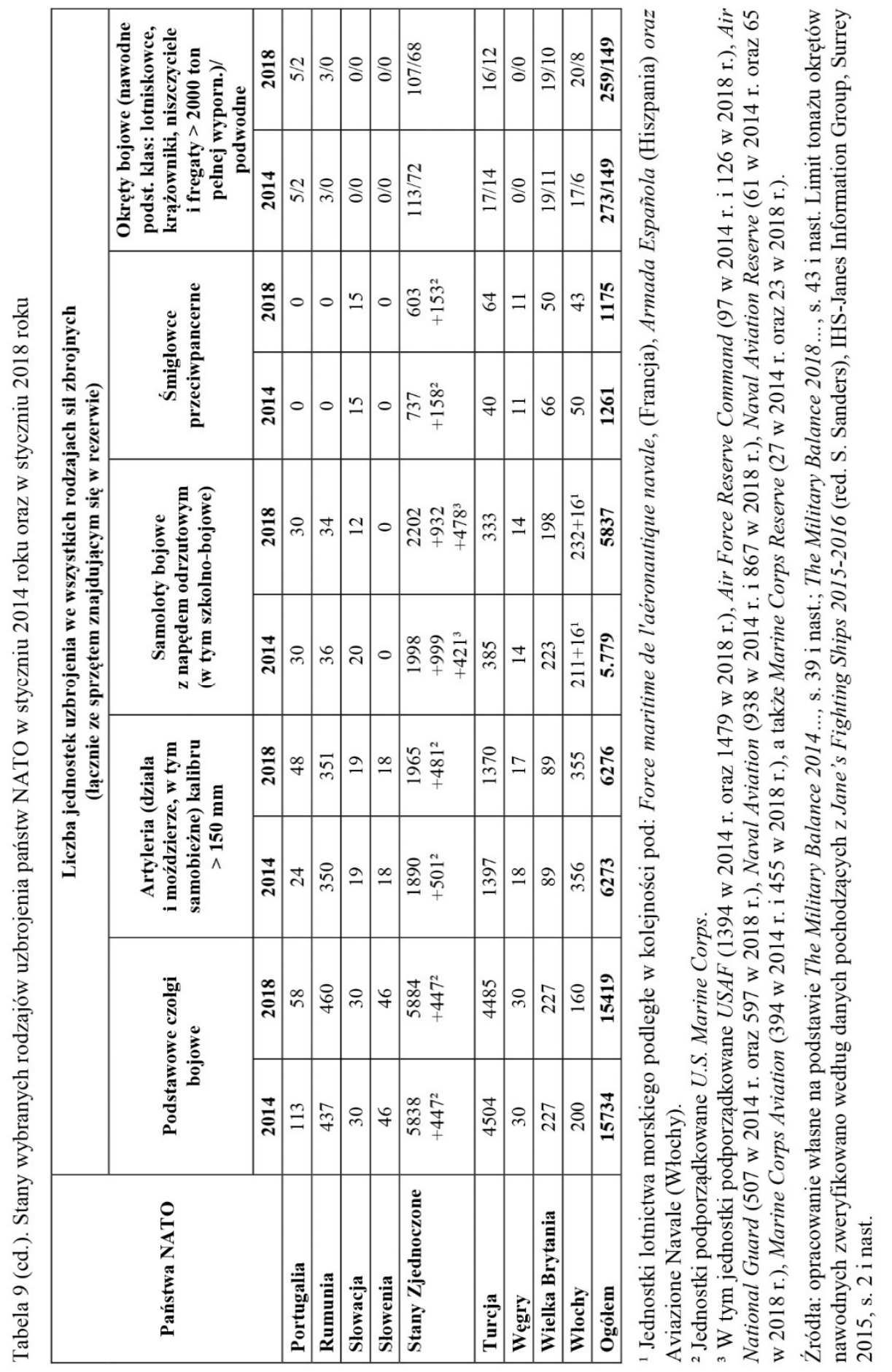


Tabela 10. Udział i dynamika wzrostu wybranych rodzajów uzbrojenia państw bałtyckich oraz Polski pomiędzy styczniem 2014 a styczniem 2018 roku

\begin{tabular}{|c|c|c|c|c|c|c|c|c|c|c|}
\hline \multirow{3}{*}{$\begin{array}{l}\text { Państwa } \\
\text { NATO }\end{array}$} & \multicolumn{10}{|c|}{$\begin{array}{l}\text { Liczba jednostek uzbrojenia we wszystkich rodzajach sił zbrojnych } \\
\text { (fącznie ze sprzętem znajdującym się w rezerwie) }\end{array}$} \\
\hline & \multicolumn{2}{|c|}{$\begin{array}{l}\text { Podstawowe } \\
\text { czołgi bojowe }\end{array}$} & \multicolumn{2}{|c|}{$\begin{array}{c}\text { Artyleria } \\
\text { (działa } \\
\text { i moździerze, } \\
\text { w tym samo- } \\
\text { bieżne) kalibru } \\
>150 \mathrm{~mm}\end{array}$} & \multicolumn{2}{|c|}{$\begin{array}{c}\text { Samoloty } \\
\text { bojowe z napę- } \\
\text { dem odrzuto- } \\
\text { wym (w tym } \\
\text { szkolno-bojowe) }\end{array}$} & \multicolumn{2}{|c|}{$\begin{array}{c}\text { Śmigłowce } \\
\text { przeciwpancerne }\end{array}$} & \multicolumn{2}{|c|}{$\begin{array}{c}\text { Okręty bojowe } \\
\text { (nawodne podst. } \\
\text { klas:lotniskowce, } \\
\text { krążowniki, } \\
\text { niszcz. i fregaty } \\
>2.000 \text { ton } \\
\text { pełnej wyporn.)/ } \\
\text { podwodne }\end{array}$} \\
\hline & 2014 & 2018 & 2014 & 2018 & 2014 & 2018 & 2014 & 2018 & 2014 & 2018 \\
\hline Estonia & 0 & 0 & 24 & 24 & 0 & 0 & 0 & 0 & $0 / 0$ & $0 / 0$ \\
\hline Litwa & 0 & 0 & 0 & 4 & 0 & 0 & 0 & 0 & $0 / 0$ & $0 / 0$ \\
\hline Łotwa & 3 & 3 & 0 & 4 & 0 & 0 & 0 & 0 & $0 / 0$ & $0 / 0$ \\
\hline Polska & 893 & 937 & 111 & 135 & 106 & 99 & 28 & 28 & $2 / 5$ & $2 / 5$ \\
\hline Ogółem & 896 & 940 & 135 & 167 & 106 & 99 & 28 & 28 & $2 / 5$ & $2 / 5$ \\
\hline $\begin{array}{l}\text { Udział } \\
\text { w całości } \\
\text { potencjału } \\
\text { NATO w \% }\end{array}$ & 5,695 & 6,096 & 2,152 & 2,661 & 1,834 & 1,696 & 2,220 & 2,383 & $\begin{array}{l}0,733 / \\
3,356\end{array}$ & $\begin{array}{l}0,772 / \\
3,356\end{array}$ \\
\hline
\end{tabular}

Źródła: opracowanie własne na podstawie The Military Balance 2014..., s. 39 i nast.; The Military Balance 2018..., s. 43 i nast.

\section{THE INCREASE IN THE IMPORTANCE OF MILITARY PARTICIPATION OF THE BALTIC STATES AND POLAND WITHIN NATO AFTER THE UKRAINIAN CRISIS}

The annexation of the Crimea and the seizure of two regions of Ukraine by Russia or the supported pro-Russian armed groups led in 2014 to a clear increase in the geopolitical significance of NATO's eastern flank. In particular, this applied to four countries located in the central part of the eastern border of the alliance: Estonia, Latvia, Lithuania and Poland. The share of military potential of these countries in relation to the entire potential (of all countries) of NATO was much less noticeable, although not less important in 2014-2018. The election of Donald Trump as the new US president in January 2017 and his demands to increase investments for defense among NATO members only accelerated changes in this area in many countries. These changes concerned the purchase of military equipment, the creation of new military organizations, such as the Military of Territorial Defense in Poland or attempts to become independent from Russia on economic matters. Predictions of, e.g. Fukuyama about the end of history has not worked. Currently only owning quite numerous and modern armed forces, allocating the appropriate amount of budget expenses for this purpose and having allies can only guarantee security for states. As a result of the analyzes carried out, the authors stated that it concerned, among others such issues as: increasing the personal conditions of the armed forces (in particular land forces) and military expenditure. Although the highest dynamics in both quoted parameters was demonstrated by Lithuania (which at the same time placed it in the first place in the entire North Atlantic Pact), traditionally, as before 2014, the highest personal states of the armed forces were still maintained by Poland, and the highest share of 
military expenditure in relation to GDP - Estonia. However, the largest contribution to NATO's potential from the analyzed countries (specifically only Poland) concerned a relatively large number of tanks.

Keywords: NATO, potential, GDP, armed forces.

DOI: $10.7862 /$ rz.2018.hss.51

Przestano do redakcji: lipiec $2018 r$.

Przyjęto do druku: wrzesień 2018 r. 
